\title{
Aksesibilitas website dan reputasi online marketplace reksadana
}

\author{
Hanny Hafiar ${ }^{1}$, Priyo Subekti ${ }^{2}$, Yanti Setianti ${ }^{3}$, Kholidil Amin ${ }^{4}$ \\ Universitas Padjadjaran, Bandung, Indonesia
}

\begin{abstract}
ABSTRAK
Marketplace reksadana online mempermudah masyarakat yang memiliki minat untuk melakukan investasi. Marketplace reksadana online menawarkan serta menjual produk reksadana kepada masyarakat yang menjadi target sasarannya melalui digital platform. Terdapat sejumlah informasi terkait investasi pada setiap website marketplace reksadana online. Informasi tersebut sangat penting untuk diketahui oleh para investor dan calon investor dari berbagai kalangan, termasuk para investor dan calon investor dari kalangan penyandang disabilitas. Hambatan aksesibilitas terhadap informasi yang terkandung dalam website akan memberikan hambatan tertentu bagi penyandang disabilitas untuk berpartisipasi dalam dunia investasi. Sejumlah literatur menunjukkan keterkaitan antara aksesibilitas dengan reputasi. Oleh karena itu, tujuan penelitian ini adalah untuk melakukan evaluasi terhadap sejumlah website marketplace reksadana online dari aspek aksesibilitas dan reputasi online. Metode yang digunakan dalam penelitian ini adalah metode kuantitatif dengan melakukan evaluasi. Alat evaluasi aksesibilitas yang digunakan adalah aXe Devtools, dengan menggunakan WCAG 2.0 sebagai standar. Sedangkan untuk evaluasi reputasi online dilakukan melalui pengecekkan skor Search Engine Optimization (SEO) dengan menggunakan alat Lighthouse Report Review dan SEO Site Checkup. Hasil penelitian mengungkapkan bahwa website marketplace reksadana online yang diteliti pada penelitian ini masih memiliki sejumlah isu aksesibilitas yang dapat menghambat aksesibilitas informasi bagi penggunanya, termasuk dari kalangan penyandang disabilitas. Sedangkan hasil pengecekkan skor SEO menunjukkan angka yang cukup baik.
\end{abstract}

Kata-kata Kunci: Aksesibilitas; reputasi; website; marketplace online; penyandang disabilitas

\section{Website accessibility and online reputation of the investment marketplace ABSTRACT}

The online investment marketplace makes it easier for people interested in investing. The online investment marketplace offers and sells mutual fund products to target communities through digital platforms. There are several investment-related information on each online investment marketplace website. This information is essential for investors and potential investors from various social backgrounds, including those with disabilities. However, the barriers to accessibility to the information contained in the website will provide typical hindrances for persons with disabilities to participate in the investment world. Some recent research publications show the relationship between accessibility and reputation. Therefore, this study aims to evaluate some online investment marketplace websites from online accessibility and reputation. The method used in this study is a quantitative method of website evaluation. The accessibility evaluation tool used is aXe Devtools, using WCAG 2.0 standard. Online reputation evaluation implementation is through Search Engine Optimization (SEO) scores checking using the lighthouse report review tool and SEO site checkup. The study results reveal that the online investment marketplace website still has many accessibility issues that can hinder the accessibility of information for users, including for people with disabilities. At the same time, the results of SEO score checking show a relatively acceptable score.

Keywords: Accessibility; reputation; website; online investment marketplace; persons with disabilities

Korespondensi: Dr. Hanny Hafiar, M.Si. Universitas Padjadjaran. J1. Raya Bandung Sumedang KM 21, Sumedang, Jawa Barat, Indonesia, 45363.Email: hanny.hafiar@unpad.ac.id 


\section{PENDAHULUAN}

Perkembangan teknologi komunikasi membuat aktivitas komunikasi pemasaran lebih banyak menggunakan media digital. Kegiatan promosi, penawaran, negosiasi, kesepakatan dan transaksi bisnis sudah dilakukan oleh pelaku bisnis melalui digital platform. Aktivitas komunikasi pemasaran yang dilakukan melalui digital platform, salah satunya dilakukan oleh marketplace reksadana. Markeplace reksadana merupakan sebuah ajang bisnis yang menyediakan produk-produk reksadana yang ditawarkan oleh para Manajer Investasi kepada publik. Marketplace reksadana berperan sebagai Agen Penjual Efek Reksadana (APERD) dan menawarkan serta menjual produk reksadana kepada masyarakat yang menjadi target sasarannya.

Kini, marketplace reksadana tersedia dalam digital platform yang bersifat online. Perkembangan marketplace reksadana online memudahkan para investor pemula yang berminat untuk melakukan investasi. Saat ini, sudah banyak platform reksadana online yang mudah untuk diakses dan digunakan. Jika diamati, telah banyak platform marketplace reksadana yang melakukan promo disertai dengan penawaran berbagai bonus dan keuntungan pada laman websitenya.

$$
\text { Marketplace reksadana online }
$$

mempermudah masyarakat yang memiliki minat untuk melakukan investasi untuk memperoleh informasi. Ketersediaan informasi tentang reksadana secara online membuka peluang bagi para investor dan calon investor untuk mengakses, membandingkan, dan menentukan jenis investasi yang diperkirakan akan memberikan keuntungan finansial dalam tempo tertentu.

Peningkatan populasi dan pasar ekonomi di Indonesia telah menghasilkan pemahaman baru tentang investasi seperti reksadana. Pada dasarnya literasi keuangan seseorang akan sejalan dengan keputusan investasi. Hal ini disebabkan individu telah memahami tingkat risiko dan tingkat pengembalian yang akan diperoleh di masa yang akan datang. Sebuah hasil penelitian menunjukkan bahwa literasi keuangan berpengaruh terhadap keputusan investasi. Hasil ini juga menunjukkan kesamaan pola dengan penelitian di negara maju dan negara berkembang (Baihaqqy et al., 2020). Pemahaman mengenai tingkat risiko dan tingkat pengembalian investasi diperoleh dari penyerapan informasi melalui berbagai media, termasuk informasi dari website marketplace reksadana online.

Guna peningkatan pemahaman mengenai tingkat risiko dan tingkat pengembalian investasi, maka salah satu kebutuhan masyarakat investor adalah mampu mengakses informasi 
Tabel 1 Nama dan URL marketplace reksadana online

\begin{tabular}{ccccc}
\hline Reksadana & URL & Daily Visitor & Monthly Visitor & Yearly Visitor \\
\hline Bibit & https://bibit.id/ & 4651 & 139530 & 1697615 \\
Invisee & http://invisee.com/ & 131 & 3930 & 47815 \\
Ajaib & https://ajaib.co.id/ & 15708 & 471240 & 5733420 \\
Kelola & https://kelolaapp.com/ & 67 & 2010 & 24455 \\
Bareksa & bareksa.com & 5281 & 158430 & 1927565 \\
Raiz & https://raizinvest.id/ & 331 & 9930 & 120815 \\
Xdana & https://xdana.com/ & 322 & 9660 & 117530 \\
Tanamduit & http://tanamduit.com/ & 461 & 13830 & 168265 \\
Moduit & https://moduit.id/ & 257 & 7710 & 93805 \\
\hline
\end{tabular}

Sumber: Statshow.com pada 30 Agustus 2021

dari website marketplace reksadana online. mengunjungi tempat transaksi. Dapat dikatakan, Jenis informasi yang dibutuhkan antara lain seluk beluk mengenai manajer investasi, produk reksadana, pilihan investasi, simulasi investasi, cara kerja investasi, serta membidik peluang investasi yang efektif. Selain itu, informasi tentang testimoni dan diskusi tentang investasi juga merupakan salah satu informasi yang dibutuhkan para investor dan calon investor saat mengunjungi platform marketplace reksadana online.

Terdapat sembilan platform marketplace reksadana online terbaik yang dirujuk dari laman sebuah situs online Irfan+ (Irfan, 2020). Pada Tabel 1 ditampilkan nama dan alamat URL ke sembilan marketplace reksadana online yang disertai dengan data kunjungan harian, bulanan dan tahunan terhadap setiap website.

Platform marketplace reksadana online dapat diakses dari rumah tanpa harus ajang bisnis ini secara langsung bersifat efektif dan efisien dalam menghemat waktu, tenaga, dan biaya transportasi. Dengan demikian, marketplace reksadana online juga dapat membantu para investor dan calon investor yang mengalami keterbatasan mobilitas untuk berinvestasi. Termasuk para investor dan calon investor dari kalangan penyandang disabilitas.

Sayangnya website yang dibuat dan dikembangkan oleh perusahaan marketplace reksadana cenderung belum memenuhi ketentuan aksesibilitas. Padahal para investor dan calon investor dari kalangan penyandang disabilitas membutuhkan aksesibilitas informasi agar dapat memperoleh informasi tentang investasi secara jelas, lengkap dan akurat. Salah satu tantangan utama yang dihadapi bidang aksesibilitas adalah reputasi aksesibilitas di antara pengembang Web. Aksesibilitas dicirikan 
sebagai anti-inovasi, anti-kreativitas (AbouZahra \& Brewer, 2019). Padahal aksesibilitas sesungguhnya dapat berdampak pada reputasi digital sebuah lembaga, sebab aksesibilitas merupakan salah satu faktor penting dalam membentuk reputasi online (Yu \& Han, 2021). Hal ini senada dengan pernyataan yang menyebutkan bahwa terdapat risiko yang berdampak nyata bagi sebuah merek manakala tidak memenuhi aspek aksesibilitas (Kitterman, 2021).

Selain itu, terdapat persyaratan Search Engine Optimization (SEO) yang bersinggungan dengan aksesibilitas, seperti menyediakan konten yang berkualitas dan dapat diakses serta menerapkan desain intuitif dan universal untuk semua pengguna. Sebagian besar aspek teknis seperti penggunaan semantik yang tepat, teks alternatif deskriptif di konten visual, struktur header yang terorganisir, tag judul, dan aspek lain yang berkaitan dengan kompatibilitas situs. Kepatuhan terhadap aspek-aspek tersebut akan membuat website dapat diakses oleh berbagai jenis navigasi seperti navigasi keyboard ataupun pembaca layar yang digunakan oleh penyandang disabilitas dengan gangguan penglihatan (AccessiBe, 2019). Berdasarkan hal tersebut maka dapat diketahui posisi penting aksesibilitas bagi reputasi lembaga ataupun produk.

Reputasi lembaga di ranah online dapat ditinjau dari SEO. Hal ini mengacu pada pernyataan bahwa manajemen reputasi online adalah cara untuk memantau dan mengelola reputasi perusahaan, dengan tujuan menghilangkan ulasan negatif pada hasil mesin pencari (SEO) (Attuluri \& Mehta, 2018). Teknik optimasi mesin pencari (SEO) ini akan mengarahkan pencarian ke posisi pertama dalam hasil pencarian organik (Veglis \& Giomelakis, 2020). Artinya, aksesibilitas dan reputasi online merupakan dua hal yang berkaitan satu sama lain.

Secara prinsip, informasi pada sebuah website harus dapat diakses secara utuh, namun ada kalanya pihak pengembang website belum dapat memenuhi standar aksesibilitas secara penuh. Terdapat beberapa hasil penelitian terdahulu yang menunjukkan adanya masalah aksesibilitas pada website. Di antaranya masalah aksesibilitas pada website di Indonesia yang dikelola pemerintah, yaitu website Kementerian dan Lembaga Negara, dengan hasil beberapa website tingkat kesalahannya masih sangat tinggi (Masyhur, 2015), aksesibilitas website Pemerintah Provinsi di Indonesia yang menunjukkan bahwa masalah yang terbanyak terdapat pada bagian prinsip Perceivable (Deastu, 2020).

Penelitian senada juga dilakukan pada website perguruan tinggi, hasilnya menunjukkan bahwa 23,9\% perguruan tinggi 
termasuk kategori inaccessible (Frandini et al., 2018), website Perguruan Tinggi Negeri di Jawa Barat belum sepenuhnya memenuhi syarat aksesibilitas website. Hal ini disebabkan karena masih terdapat beberapa pelanggaran terhadap beberapa kriteria dari pedoman WCAG 2.0 dalam hal aksesibilitas website (Arasid et al., 2018).

Pelanggaran terhadap standar aksesibilitas juga didapati pada website lembaga bisnis. Hasil evaluasi aksesibilitas situs marketplace yang paling banyak dikunjungi di Indonesia menunjukkan bahwa masih terdapat pelanggaran terhadap standar tertentu dalam pedoman WCAG (Hafiar et al., 2022). Sedangkan penelitian lain menunjukkan gejala temuan yang senada dari pengecekkan terhadap repository (Saripudin et al., 2019).

Fenomena yang sama juga diamati dan ditemukan peneliti pada sejumlah marketplace platform reksadana online. Padahal di masa pandemi ini, diharapkan semua pihak dapat membuka kesempatan dan peluang usaha yang dapat meningkatkan kemampuan ekonomi masyarakat. Marketplace reksadana online sesungguhnya memiliki kesempatan untuk memperluas dan memperbesar peluang ekonomi bagi masyarakat. Terlebih masa pandemi telah membatasi mobilitas individu. Platform online yang ditawarkan marketplace reksadana setidaknya memberi kesempatan masyarakat untuk melakukan bisnis tanpa keharusan melakukan mobilitas.

Secara umum, aksesibilitas tak hanya bermanfaat bagi penyandang disabilitas, namun juga bagi masyarakat umum. Artinya, peningkatan kualitas aksesibilitas pada website marketplace reksadana online bukan hanya akan berdampak positif bagi para investor dan calon investor dari kalangan penyandang disabilitas, namun juga masyarakat umum. Berdasarkan tingkat urgensi dari kondisi ini, maka peneliti melaksanakan penelitian yang bertujuan untuk melakukan kajian berupa evaluasi terhadap sejumlah website marketplace reksadana online dari aspek aksesibilitas dan reputasi online.

\section{METODE PENELITIAN}

Metode yang digunakan dalam penelitian ini adalah metode kuantitatif dengan melakukan evaluasi. Pada saat penelitian ini dilakukan, peneliti menggunakan WCAG 2.0 sebagai standar. Hal ini disebabkan standar WCAG 2.0 menempatkan bobot yang signifikan pada kebutuhan untuk mengatasi masalah aksesibilitas yang dihadapi oleh orang yang mengalami gangguan penglihatan dan pengguna alat bantu pembaca layar. Dari 12 pedoman di WCAG 2.0, terdapat 10 item yang secara langsung bersifat relevan untuk mengatasi masalah aksesibilitas web yang dihadapi oleh penyandang disabilitas penglihatan (Abou- 
Zahra \& Brewer, 2019). Adapun penyandang disabilitas dengan gangguan penglihatan saat ini cenderung menggunakan alat bantu pembaca layar, namun penggunaan alat pembaca layar saat ini sebagian besar terbatas pada penggunaan dari antarmuka keyboard dan alat perbesaran layar yang bergantung pada penggunaan mouse dan keyboard.

Sampling website yang dievaluasi mengacu pada website marketplace reksadana online yang termasuk ke dalam website marketplace reksadana online terpopuler berdasarkan perankingan sebuah situs. Alasan pemilihan ini didasari argumen bahwa marketplace reksadana online ini termasuk marketplace reksadana online yang memiliki jumlah visitor tinggi dan memiliki reputasi tertentu di kalangan investor berbasis online.

Alat evaluasi aksesibilitas yang digunakan adalah aXe DevTools dari Deque. Pemilihan ini mengacu pada pernyataan bahwa aXe adalah alat evaluasi yang bersifat fleksibel dan mudah digunakan (Rubano \& Vitali, 2020), menunjukkan jenis masalah dan bagaimana mengatasinya; memberikan kemungkinan untuk menyimpan hasil; antarmuka pengguna yang baik dan intuitif; dan memandu pengguna untuk mengevaluasi hasilnya (Frazão \& Duarte, 2020).

Sedangkan untuk alat yang digunakan untuk mengukur reputasi digital adalah lighthouse report viewer dan SEO site checkup. Pada tahap pemeriksaan dengan menggunakan beberapa alat tersebut, jika diketahui terdapat hambatan aksesibilitas pemeriksaan maka hasil pengecekkan tersebut tidak disertakan dalam tabel dan gambar hasil pengecekkan.

\section{HASIL DAN PEMBAHASAN}

Website menjadi salah satu saluran informasi yang dimanfaatkan oleh perusahaan sekuritas atau marketplace reksadana untuk mengenalkan jasa atau produk mereka, dan menyebarkan informasi yang dibutuhkan oleh publik yang mungkin tertarik untuk menjadi investor reksadana. Oleh karena itu, aksesibilitas sebuah website menjadi penting, dan dapat dievaluasi untuk selanjutnya dilakukan perbaikan oleh pengembang website. Penelitian ini mengevaluasi aksesibilitas dari delapan situs sekuritas reksadana terbaik di Indonesia, dan mendapatkan beberapa temuan masalah terkait aksesibilitas website. Mengacu pada Sims (Sims, 2016b), kategori dampak masalah aksesibilitas digolongkan menjadi "critical", "serious", "moderate, dan "minor". Dampak kritis adalah penghambat yang mutlak mengganggu aksesibilitas website, dan dampak serius adalah penghambat yang berpotensi besar mengganggu aksesibilitas website oleh pengguna, terlebih bagi penyandang disabilitas (Sims, 2016a) 


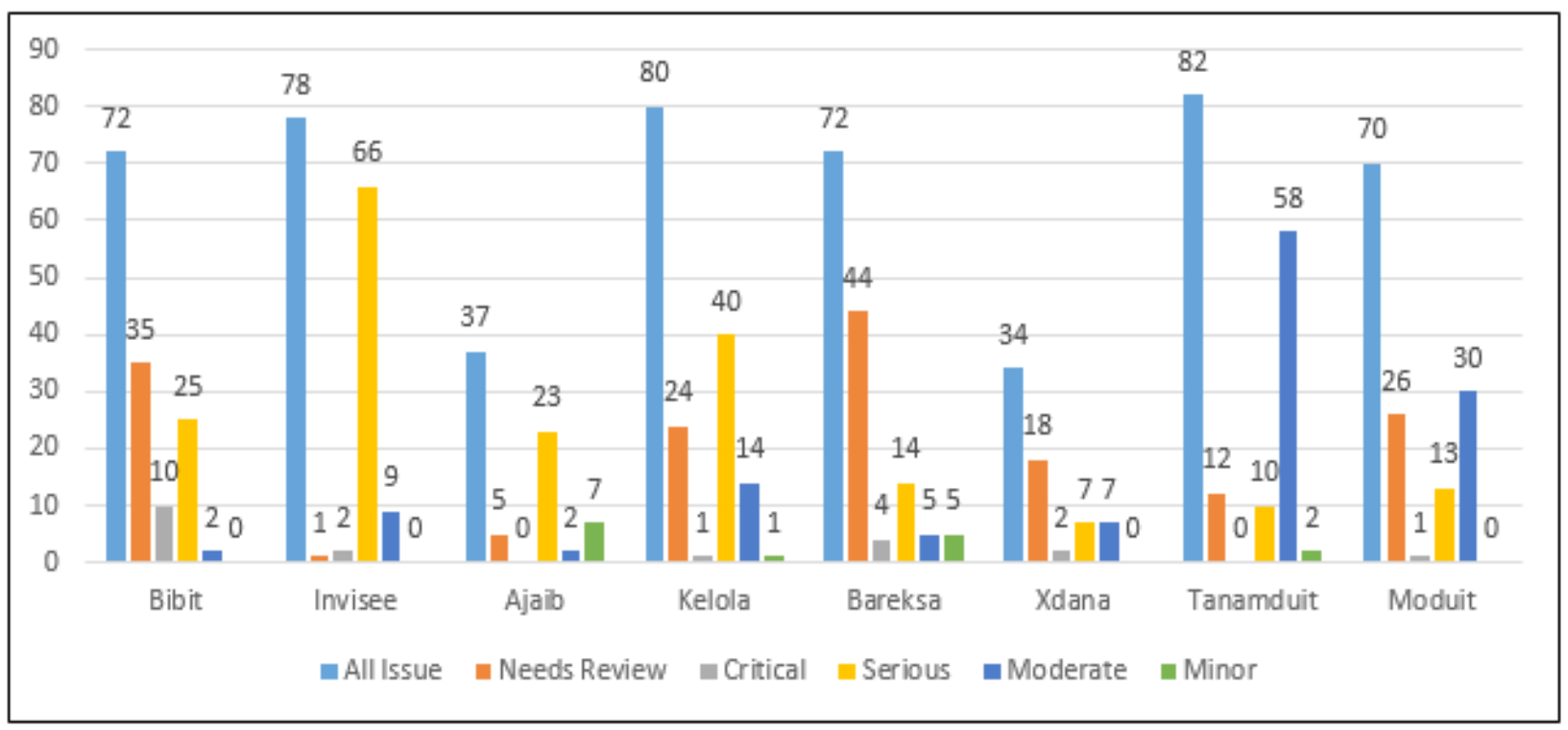

Sumber: AXE DevTools per 30 Agustus, 2021

\section{Gambar 1 Jumlah dan Jenis Dampak Aksesibilitas}

Hasil evaluasi delapan website marketplace reksadana di Indonesia (selengkapnya di Gambar 1) menunjukkan bahwa website marketplace reksadana yang paling sedikit memiliki isu aksesibilitas adalah Xdana. Secara keseluruhan dari delapan website masalah aksesibilitas yang berdampak "serious" adalah yang tertinggi yakni sebesar $37.71 \%$ atau ratarata 24.75 masalah per website. Temuan juga menunjukkan bahwa tidak banyak website yang memiliki masalah aksesibilitas berdampak “minor" yakni 3.45\% saja atau 2.22 masalah per website. Lebih lanjut, rentang isu aksesibilitas terbesar adalah isu yang berdampak "serious" yakni 7-66 isu per website. Sementara itu, rentang isu aksesibilitas terkecil adalah isu yang berdampak "minor" dengan 0-7 isu per website.
Lebih lanjut, pada website yang dievaluasi, terdapat $22.2 \%$ atau dua website saja yang tidak memiliki isu aksesibilitas "critical". Namun, hasil evaluasi juga menunjukkan semua website masih memiliki dampak aksesibilitas yang berdampak "serious". Temuan juga menunjukkan bahwa terdapat $44.4 \%$ website yang dievaluasi tidak memiliki isu aksesibilitas dengan dampak "minor" (selengkapnya di Gambar 1). Secara umum, hasil ini menunjukkan bahwa masalah aksesibilitas yang berdampak serius adalah masalah yang paling dominan dialami oleh website marketplace reksadana. Implikasinya adalah para pengguna sangat mungkin mengalami beberapa hambatan yang berarti saat mengakses website marketplace reksadana untuk mencari informasi, sehingga 
secara berkelanjutan jika tidak ada perbaikan maka berpotensi mengurangi kenyamanan atau minat para pengguna untuk mengaksesnya kembali.

Berdasarkan tiap kategori dampak aksesibilitas yang ada di Gambar 1, Bibit adalah reksadana yang paling banyak memiliki masalah aksesibilitas website berdampak kritis, sedangkan website reksadana yang paling sedikit memiliki isu aksesibilitas berdampak kritis adalah Xdana dan Ajaib. Lebih lanjut, website reksadana yang paling banyak memiliki isu aksesibilitas berdampak serius adalah Invisee, sedangkan Xdana adalah reksadana yang paling sedikit memiliki masalah aksesibilitas website berdampak serius. Dalam hal masalah aksesibilitas website berdampak moderat, situs tanamduit adalah yang terbanyak memiliki isu ini, sedangkan Ajaib adalah situs reksadana yang paling sedikit.

Kemudian, Ajaib adalah reksadana yang paling tinggi memiliki isu aksesibilitas berdampak minor. Sementara itu, empat website lainnya yakni Xdana, Invisee, moduit, dan bibit, masing-masing paling sedikit memiliki isu aksesibilitas berdampak minor. Secara spesifik, temuan ini menjadi informasi bagi masingmasing pengembang untuk memperbaiki atau meningkatkan aksesibilitas website-nya, khususnya bagi marketplace reksadana yang memiliki masalah aksesibilitas berdampak kritis atau serius yang masih tinggi. Banyaknya masalah aksesibilitas yang berdampak kritis atau serius berpotensi membuat para pengguna marketplace reksadana tertentu mengalami banyak ketidaknyamanan saat mengakses websitenya, dan mungkin itu dapat membuat marketplace reksadana tersebut kalah saing dengan para kompetitornya yang lebih nyaman diakses.

Selain masalah-masalah aksesibilitas yang telah terkategorisasi berdasarkan dampaknya, hasil evaluasi delapan website juga mengungkap bahwa terdapat beberapa aksesibilitas dengan status "need review" yang ditemukan, yakni isu yang memerlukan peninjauan lebih lanjut (selengkapnya di Gambar 1). Bareksa adalah reksadana yang memiliki masalah aksesibilitas dengan status "need review" paling banyak, sedangkan website Invisee adalah yang paling sedikit memilikinya. Karena keterbatasan alat mengevaluasi isu tersebut, peran ahli web dibutuhkan untuk mengevaluasi isuisu aksesibilitas yang memerlukan penilaian secara manual (Ismail et al., 2018; Ismail \& Kuppusamy, 2019). Dalam konteks penelitian ini, masalah aksesibilitas dengan status "need review" juga penting untuk diperhatikan dan dilakukan perbaikan oleh pengembang website masing-masing reksadana mengingat angka rata-ratanya juga tinggi yakni mencapai 20.63 per website. Perbaikan diperlukan agar 
Tabel 2 Jenis dan Jumlah Permasalahan Aksesibilitas

\begin{tabular}{|c|c|c|c|}
\hline No & Jenis Masalah & $\mathrm{F}$ & Jumlah Web \\
\hline 1 & Elements must have sufficient color contrast & 266 & 8 \\
\hline 2 & All page content should be contained by landmarks & 107 & 5 \\
\hline 3 & Links must have discernible text & 55 & 5 \\
\hline 4 & id attribute value must be unique & 14 & 3 \\
\hline 5 & Images must have alternate text & 11 & 3 \\
\hline 6 & Heading levels should only increase by one & 8 & 5 \\
\hline 7 & Document should have one main landmark & 6 & 4 \\
\hline 8 & Elements must only use allowed ARIA attributes & 6 & 4 \\
\hline 9 & Zooming and scaling should not be disabled & 5 & 4 \\
\hline 10 & $\begin{array}{l}<\mathrm{ul}>\text { and }<\mathrm{ol}>\text { must only directly contain }<\mathrm{li}>,<\text { script }>\text { or } \\
<\text { template }>\text { elements }\end{array}$ & 4 & 2 \\
\hline 11 & ARIA attributes must conform to valid values & 4 & 1 \\
\hline 12 & ARIA input fields must have an accessible name & 4 & 2 \\
\hline 13 & Ensure interactive controls are not nested & 4 & 2 \\
\hline 14 & Frames should be tested with axe-core & 4 & 3 \\
\hline 15 & $<$ video $>$ elements must have captions & 3 & 3 \\
\hline 16 & ARIA commands must have an accessible name & 3 & 2 \\
\hline 17 & Ensures landmarks are unique & 3 & 3 \\
\hline 18 & IDs of active elements must be unique & 3 & 2 \\
\hline 19 & IDs used in ARIA and labels must be unique & 3 & 1 \\
\hline 20 & Page should contain a level-one heading & 2 & 2 \\
\hline 21 & Certain ARIA roles must contain particular children & 2 & 1 \\
\hline 22 & Frames must have an accessible name & 2 & 1 \\
\hline 23 & Headings should not be empty & 1 & 1 \\
\hline 24 & $<$ html $>$ element must have a lang attribute & 1 & 1 \\
\hline 25 & ARIA hidden element must not contain focusable elements & 1 & 1 \\
\hline 26 & Document should not have more than one main landmark & 1 & 1 \\
\hline 27 & Form elements should have a visible label & 1 & 1 \\
\hline 28 & Links with the same name have a similar purpose & 1 & 1 \\
\hline \multicolumn{2}{|r|}{ Total Issue } & \multicolumn{2}{|r|}{525} \\
\hline
\end{tabular}

Sumber: AXE DevTools per 30 Agustus, 2021

kedepannya tidak menjadi masalah yang website masing-masing reksadana sebelum serius bahkan kritis. Perbaikan yang dilakukan dapat mengoptimalkan aksesibilitas website menentukan keputusan investasi.

Hasil evaluasi juga menemukan beberapa reksadana ketika diakses oleh para penggunanya, masalah aksesibilitas yang dialami oleh websitekhususnya penyandang disabilitas, yang website reksadana. Ada 28 jenis isu yang mungkin membutuhkan informasi terkait di teridentifikasi sebagai masalah aksesibilitas. 
Dari 28 isu tersebut, terdapat tiga isu yang paling banyak dialami oleh website-website reksadana yang dievaluasi yakni "elements must have sufficient colour contrast"; "all page content should be contained by landmarks", dan "links must have discernible text". Lebih lanjut, memang terdapat juga isu-isu lainnya yang menganggu aksesibilitas situs-website reksadana di Indonesia (selengkapnya di Tabel 2). Dari 28 masalah yang teridentifikasi, masalah "elements must have sufficient colour contrast" adalah satu-satunya masalah dialami oleh semua website yang evaluasi dalam penelitian ini. Sementara itu, masalah "all page content should be contained by landmarks" dan "links must have discernible text" dialami oleh lima website saja. Kemudian, dari semua masalah yang teridentifikasi, terdapat $36 \%$ masalah aksesibilitas yang khusus hanya dialami oleh satu website saja. Hasil ini menunjukkan bahwa ada masalah-masalah aksesibilitas yang umum atau khusus dialami oleh website reksadana.

Terkait masalah terbanyak yang dialami oleh semua website yakni ketidakcukupan kontras warna, hal tersebut tentu dapat menjadi penghambat para pengguna website, terutama para penyandang disabilitas buta warna atau low vision. Mereka akan kesusahan untuk melihat tampilan website dengan jelas, dan membaca konten yang disajikan oleh website tertentu dengan nyaman. Indikator kontras warna menggambarkan aksesibilitas website dari perspektif kontras warna pada elemen visual sebuah website. Oleh karena itu, pengembang website perlu mengacu pada standar atau pedoman mengenai kontrasi warna dalam mengembangkan websitenya. AbouZahra dan Brewer (Abou-Zahra \& Brewer, 2019) menjelaskan bahwa WCAG menentukan ambang batas terkait kontras warna antara warna latar belakang dan latar depan yakni 4,5:1, bahkan 7:1 untuk memastikan testabilitas kontras warna pada sebuah website. Kontras warna yang kurang baik antara warna latar belakang dan latar depan akan menyebabkan kesulitan membedakan tombol interaktif pada saat mengakses website, khususnya bagi penyandang buta warna (Calvo et al., 2016).

Temuan juga menunjukan bahwa beberapa website memiliki isu aksesibilitas yang berulang. Hal ini terlihat dari beberapa isu aksesibilitas yang jumlahnya melebihi jumlah website yang dievaluasi seperti "elements must have sufficient colour contrast" dan "all page content should be contained by landmarks" yang masingmasing berjumlah 266 dan 107. Artinya, satu website dapat mengalami pengulangan masalah dengan jenis masalah yang sama. Oleh karena itu, evaluasi aksesibilitas sebuah website adalah hal penting yang harus dilakukan untuk mengidentifikasi masalah-masalah, khususnya masalah yang berulang. Intensitas masalah 


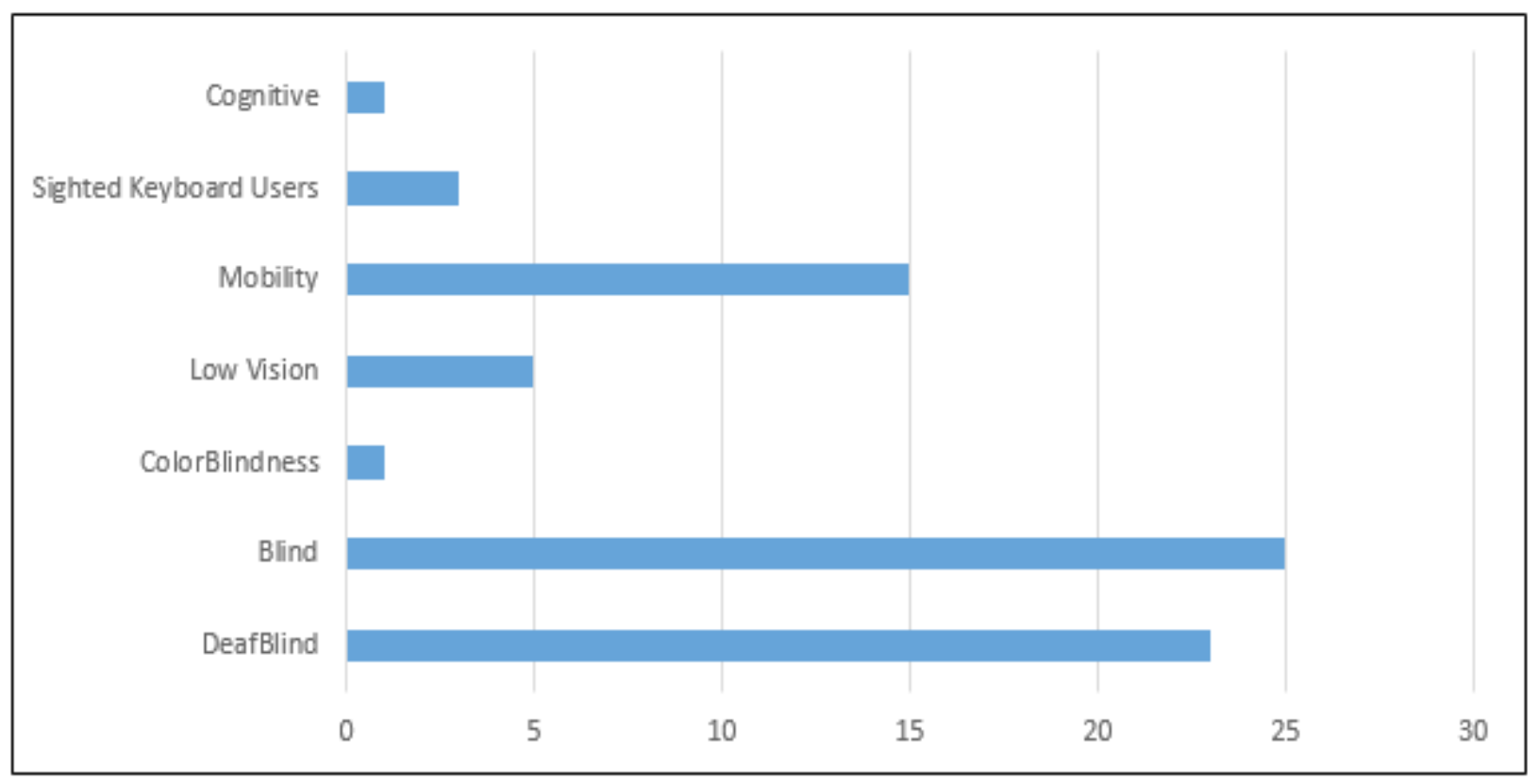

Sumber: AXE DevTools per 30 Agustus, 2021

Gambar 2 Jenis Disabilitas yang Mengalami Keterdampakkan dari Permasalahan Aksesibilitas

yang berulang bisa jadi disebabkan oleh ketidaktahuan pengembang web akan masalah yang dialami, kurang cakapnya pengembang dalam memperbaiki masalah, atau bahkan pengabaian masalah oleh pengembang web baik disengaja maupun tidak disengaja.

Masalah-masalah aksesibilitas website yang dipaparkan pada Tabel 2 dapat juga berdampak kepada para penggunanya yang memiliki disabilitas tertentu (selengkapnya di Gambar 2). Pengguna website yang mengalami kebutaan dan/atau tuli adalah golongan disabilitas yang paling terdampak karena adanya masalah aksesibilitas pada website tertentu, sementara itu pengguna dengan keterbatasan kognitif dan buta warna adalah golongan disabilitas yang paling sedikit terdampak isu aksesibilitas website.

Hambatan aksesibilitas setidaknya akan mengurangi kenyamanan pengguna untuk menjelajahi website dan berpeluang menghalangi pengunjung untuk memperoleh informasi secara lengkap dan jelas. Hambatan aksesibilitas juga dapat menimbulkan keengganan pengguna untuk kembali melakukan akses terhadap website. Sebagaimana penelitian sebelumnya berpendapat bahwa website dengan masalah aksesibilitas akan menghalangi pengunjung untuk datang (Velásquez et al., 2004). Oleh karena itu, aksesibilitas terhadap website merupakan faktor penting yang harus dipertimbangkan oleh para pengembang website.

Setiap hambatan aksesibilitas akan 
menimbulkan dampak dengan derajat tertentu kepada pengguna. Salah satu contohnya adalah kepada pengguna disabilitas dan juga pengguna dari kalangan usia lanjut yang telah mengalami penurunan kondisi sensorik maupun motorik. Setiap penyandang disabilitas memiliki cara akses informasi yang berbeda, sehingga memiliki kebutuhan berbeda pula. Perbedaan kebutuhan pengguna dari kalangan penyandang disabilitas ini merupakan aspek yang perlu dipahami secara komprehensif oleh para pengembang website.

Terdapat hambatan aksesibilitas yang diketahui berdasarkan hasil penelitian ini yang akan memberikan dampak tertentu kepada pengguna dari kalangan penyandang disabilitas dari beberapa jenis. Keseluruhan hasil pengecekkan jumlah masalah yang terdeteksi yang berdampak pada jenis disabilitas tertentu dapat dilihat pada Gambar 2.

Dari 28 jenis masalah aksesibilitas yang terdeteksi pada website marketplace reksadana yang diteliti pada penelitian ini, diketahui bahwa jenis penyandang disabilitas yang paling sering terkena dampak adalah dari kalangan penyandang disabilitas dengan hambatan penglihatan. Terdapat sebanyak 25 atau sebesar $89 \%$ di antaranya memberikan dampak tertentu bagi penyandang disabilitas tunanetra, sebesar $82 \%$ memberikan dampak tertentu bagi penyandang disabilitas tunaganda yaitu buta tuli. Kondisi ini tentu sangat tidak menguntungkan bagi penyandang disabilitas, terutama yang memiliki hambatan penglihatan.

Informasi terkait investasi juga diperlukan oleh para penyandang disabilitas. Banyak dari mereka juga tertarik mengakses informasi terkait investasi. Minat penyandang disabilitas untuk mengakses informasi terkait investasi terlihat dari antusiasme mereka untuk mengikuti pelatihan investasi reksadana yang digelar oleh Universitas Padjadjaran. Tingginya antusiasme penyandang disabilitas untuk mendapatkan informasi terkait investasi juga terlihat dari beragamnya jumlah pertanyaan yang diajukan oleh mereka saat pelatihan investasi reksadana (Destinasi Bandung, 2021). Oleh karena itu, sebenarnya website reksadana online juga perlu memiliki aksesibilitas yang baik agar para pengguna khusunya para penyandang disabilitas yang memiliki keterbatasan tertentu tetap dapat mengakses informasi dengan baik.

Selanjutnya, hasil penelitian ini juga menyajikan hasil pengecekkan SEO yang dikaitkan dengan reputasi online. Skor SEO adalah ukuran seberapa baik aspek teknis dan tampilan yang dihadapi oleh pengguna situs yang berkontribusi pada optimalisasi mesin pencarian, dan pada akhirnya berdampak pada ranking dan traffic (Needham, 2021). Semua skor otoritas domain berkisar dari 1 hingga 100. Semakin tinggi skor yang diperoleh pada 


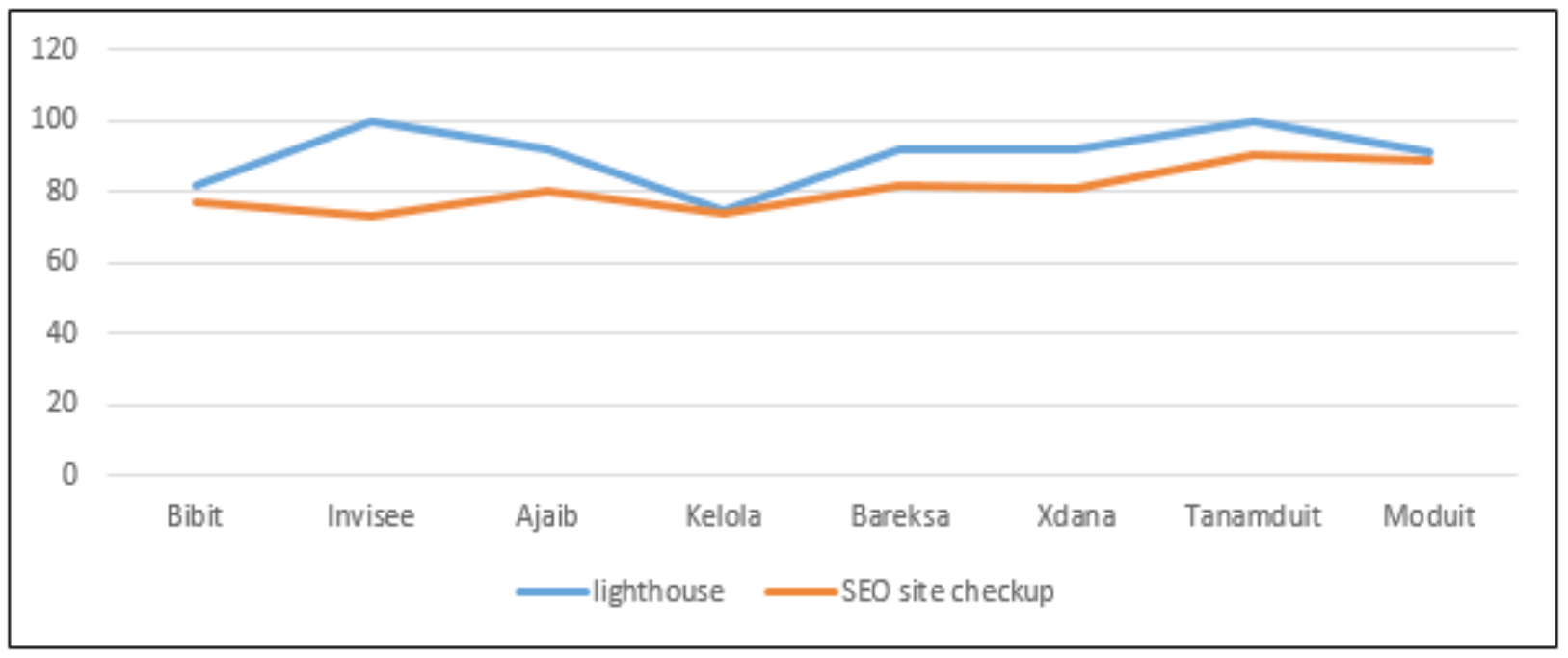

Sumber: https://googlechrome.github.io/lighthouse dan https://seositecheckup.com/analysis, 2021

\section{Gambar 3 Hasil Penilaian Skor SEO}

tes ini, semakin besar kemampuan sebuah website untuk mendapatkan peringkat yang baik. Terdapat dua kategori dasar yang diukur, yaitu aspek yang dihadapi pengguna dan aspek yang bersifat teknis. Sedangkan subkategori utama yang akan memengaruhi skor akhir peringkat website, antara lain: Konten, Teknis, Pengalaman Pengguna, dan Seluler. Berikut ini disajikan skor SEO pada delapan website yang diukur melalui dua alat.

Berdasarkan data yang ditampilkan pada Gambar 3 diketahui bahwa skor SEO dari delapan situs marketplace reksadana yang diperoleh dari lighthouse report viewer berkisar antara 75-100, dengan nilai rata-rata sebesar 90.50. Sedangkan skor SEO dari delapan situs marketplace reksadana yang diperoleh dari SEO site checkup berkisar antara 74/100-90/100, dengan nilai rata-rata sebesar 80.75. Adapun perbandingan hasil pengecekkan SEO skor melalui dua alat tersebut menunjukkan trend yang sama. Artinya kedua alat pengecekkan skor SEO ini memiliki tingkat reliabilitas yang cenderung setara, sehingga menunjukkan hasil pengecekkan dengan range nilai yang relatif sejalan.

Di pasar keuangan kontemporer, konsekuensi dari spekulasi investasi dan pengambilan keputusan yang berlandaskan pada sebuah pernyataan yang tidak berdasar ataupun desas-desus palsu bisa sangat berbahaya. Dengan munculnya internet dan teknologi komunikasi baru lainnya yang memfasilitasi penyebaran informasi yang salah, seharusnya dapat menjadi sinyal penting bagi manajer, investor, dan pemangku kepentingan lainnya untuk memperoleh pemahaman yang lebih baik agar dapat mengantisipasi faktor yang dapat 
menimbulkan rumor serta membangun strategi yang paling efektif untuk menanganinya (Kimmel, 2004). Terutama jika lembaga keuangan dan investasi ini mengembangkan produknya berbasis digital seperti marketplace reksadana online.

Marketplace sebagai bagian dari perkembangan E-commerce merupakan salah satu sektor ekonomi yang dinamis dan penting. Perkembangannya didorong oleh akses Internet yang berkembang pesat. E-commerce di seluruh dunia didominasi oleh pasar dengan pangsa pasar yang besar. Namun demikian, selalu ada keuntungan dan kerugian yang terkait dengan penggunaan pasar, baik untuk penjual maupun pembeli, untuk dipertimbangkan. Marketplace menciptakan peluang baru untuk melakukan ekspansi bisnis dalam skala yang lebih besar bagi pihak penjual produk. Perusahaan dapat berinvestasi dalam platform penjualan dan memiliki akses yang bersifat solutif dan inovatif. Walau demikian, ada banyak hal yang perlu diantisipasi dalam bisnis jenis ini, seperti persaingan yang sangat kuat dari banyaknya jumlah penjual di satu tempat, menjadi tergantung pada saluran penjualan, dan mengabaikan pertumbuhan perusahaan penjual itu sendiri (Kawa \& Wałęsiak, 2019), termasuk perusahaan investasi.

Sebagian orang berpikir bahwa berinvestasi di pasar saham merupakan hal yang sulit.
Berinvestasi membutuhkan kemampuan berfikir dan berhitung secara rasional. Ada kalanya investor cenderung menyederhanakan situasi sehingga mengarah pada terjadinya kesalahan dalam proses keputusan investasi. Namun, investor belajar dari kesalahan dan pengalaman bisnis mereka di pasar saham. Oleh karena itu, merupakan hal yang penting untuk memahami perilaku investor dan keputusan keuangan mereka di pasar saham, serta memberikan edukasi yang mempengaruhi aktivitas bisnis investor (Liivamägi, 2016). Edukasi merupakan komponen penting, yang mempengaruhi kinerja, pengambilan risiko dan partisipasi investor di pasar saham. Salah satu aktivitas edukasi dapat dilakukan dengan penyebaran informasi terkait investasi. Oleh karena itu, informasi tentang investasi sudah seyogyanya tersedia di platform marketplace reksadana online.

Ketersediaan informasi investasi di website marketplace reksadana online bukan merupakan kewajiban yang final, sebab ketersediaan informasi ini juga harus dibarengi dengan aksesibilitas terhadap informasi tersebut. Hasil penelitian ini menunjukkan masih terdapat pelanggaran terhadap standar aksesibilitas pada website marketplace reksadana online. Bukan hanya di Indonesia, fenomena pelanggaran atau belum terpenuhinya standar aksesibilitas juga banyak terjadi di negara lain, contohnya hasil evaluasi aksesibilitas yang menguji website 
perusahaan Portugis menyatakan, tingkat aksesibilitas website yang dievaluasi masih memiliki tingkat kesalahan yang signifikan tetapi sebagian besar kesalahan yang terdeteksi sesungguhnya tidak terlalu rumit untuk diperbaiki apabila ditinjau dari sudut pandang teknologi (Gonçalves et al., 2014).

Selanjutnya, fenomena pelanggaran atau belum terpenuhinya standar aksesibilitas juga banyak terjadi di berbagai bidang lain, misalnya kesehatan. Sebuah penelitian di bidang kesehatan yang meneliti 108 website yang diperoleh dari daftar website informasi kesehatan konsumen yang berasal dari layanan direktori mesin pencari Google, menyebutkan bahwa tidak ada website yang sepenuhnya dapat diakses oleh penyandang disabilitas, artinya tidak ada situs yang tidak melanggar aturan aksesibilitas website (Zeng \& Parmanto, 2004. Begitu juga dengan hasil penelitian kesehatan terkait Covid 19. Kesimpulan yang dicapai sebuah penelitian menyebutkan bahwa tidak semua informasi dari WHO dapat diakses sesuai dengan Pedoman Aksesibilitas Konten Web 2.1. Oleh karena itu penelitian ini menyarankan untuk meningkatkan aksesibilitas konten kesehatan kepada kelompok yang sangat rentan dalam pandemi (Fernández-Díaz et al., 2020).

Penelitian sejenis di bidang pendidikan juga mengemukakan hal yang senada. Hasil sebuah penelitian di bidang pendidikan menunjukkan bahwa di sebagian besar negara, meskipun pemerintah berusaha untuk memaksakan lembaga pendidikan untuk mematuhi pedoman aksesibilitas, masih perlu lebih banyak upaya untuk mematuhi pedoman tersebut. Sebagian besar lembaga pendidikan baru mengikuti kurang dari $50 \%$ dari keseluruhan pedoman (Kesswani \& Kumar, 2016). Sedangkan hasil lain menyatakan institusi pasca sekolah menengah yang diteliti dalam penelitian ini, belum ada yang menerbitkan web yang sesuai dengan Bagian 508 (Taylor, 2019), yang merupakan bagian dari standar aksesibilitas.

Artinya, terdapat fakta masalah aksesibilitas pada website lembaga tak hanya terjadi di website lembaga bisnis yang bersifat profit-oriented, namun juga terjadi di berbagai bidang vital seperti kesehatan dan pendidikan. Selanjutnya, masalah aksesibilitas pada website lembaga tak hanya terjadi di website lembaga swasta yang bersifat personal, namun juga terjadi pada website lembaga pemerintah yang memiliki kewajiban pelayanan publik. Terakhir, masalah aksesibilitas pada website tak hanya terjadi di negara berkembang namun juga terjadi di negara yang memiliki kemajuan teknologi sekalipun.

Namun demikian, permasalahan aksesibilitas di berbagai sektor yang cenderung bersifat global, tidak dapat dijadikan sebagai alasan bagi para pengembang website di 
Indonesiauntuk tidak meningkatkan kualitasnya.

Terutama jika hambatan aksesibilitas website dapat menghambat pertumbuhan sektor ekonomi seperti marketplace reksadana online. yang memiliki posisi strategis, potensial dan dapat berperan cukup krusial pada saat pandemi ini.

Oleh karena itu, dibutuhkan kesadaran pengembang website marketplace reksadana untuk mematuhi standar aksesibilitas agar dapat meningkatkan kepercayaan dan sekaligus menciptakan kepuasan konsumennya. Terutama untuk menghindarkan konsumen dari kesimpangsiuran informasi yang berpotensi menjadi penipuan. Sebab, dengan pertumbuhan kelas menengah yang cepat dengan eksposur internet, meningkatkan faktor kepercayaan dan kepuasan di e-marketplace Indonesia masih merupakan tugas berat, di mana ancaman penipuan dapat dengan mudah ditemukan (Sfenrianto et al., 2018).

Selain itu, marketplace yang berkaitan dengan keuangan bergantung pada penyaringan dan produksi informasi oleh investor, partisipasi dari sejumlah investor menciptakan persaingan ketat di antara investor. Seiring berkembangnya platform, maka akan meningkatkan intensitas penyaringan dan penyediaan informasi kepada investor. Investor yang kompeten dan canggih serta memiliki kinerja baik pun dapat menyusut ketika platform mengurangi penyediaan informasi kepada investor (Vallee \& Zeng, 2018).

Berdasarkan pernyataan tersebut dapat diketahui bahwa informasi memiliki peran penting dalam menunjang kesuksesan berinvestasi. Ketidaktersediaan informasi, pengurangan informasi, terlebih kesulitan aksesibilitas informasi bagi investor, terutama investor dan calon investor dari kalangan penyandang disabilitas dapat menghambat peluang mereka untuk berpartisipasi dalam dunia investasi. Padahal sekecil apapun peluang ekonomi tetap merupakan peluang yang harus dapat dimanfaatkan oleh semua pihak, termasuk kalangan penyandang disabilitas. Hal ini sesuai dengan tujuan negara untuk menciptakan masyarakat inklusi tanpa terkecuali.

Seperti halnya lending marketplace, marketplace reksadana juga telah dengan cepat mendapatkan pangsa pasar selama dekade terakhir. Perkembangan pesat ini memiliki peran penting implikasi pada dunia investasi. Perancangan sebagai platform dua sisi ini membawa inovasi baik di sisi peminjam maupun investor. Inovasi yang terasa adalah menyederhanakan proses aplikasi online yang menggunakan teknologi informasi berbiaya rendah untuk mengumpulkan informasi standar yang tersebar dalam skala besar (Vallee \& Zeng, 2018), termasuk dari sisi investor dan calon investor. 
Artinya keberadaan marketplace reksadana dalam platform online ini memudahkan masyarakat yang berminat untuk berinvestasi, termasuk masyarakat dari kalangan penyandang disabilitas. Namun demikian, kalangan penyandang disabilitas memiliki tantangan dan kendala tersendiri dalam mengoperasionalisasikan teknologi berbasis digital. Oleh karena itu para pengembang teknologi berupaya mengembangkan sejumlah alat bantu yang mempermudah penyandang disabilitas untuk dapat menggunakan berbagai perangkat teknologi digital.

Terdapat sejumlah alat bantu berupa perangkat lunak dan perangkat keras komputer, seperti program pengenalan suara, pembaca layar, dan aplikasi pembesaran layar, untuk membantu orang dengan gangguan mobilitas dan sensorik menggunakan komputer dan perangkat seluler. Namun demikian, ketika pengguna penyandang disabilitas memiliki akses ke alat bantu, desain konten masih dapat menimbulkan masalah dan membingungkan atau tidak dapat diakses (Kitterman, 2021). Hambatan aksesibilitas dapat menimbulkan persepsi tertentu terhadap perusahaan yang memiliki platform tersebut.

Seperti yang telah dikemukakan sebelumnya bahwa aksesibilitas memiliki kaitan dengan reputasi. Dunia digital mengubah perangkat menjadi perangkat lunak, bisnis menjadi bisnis yang serba elektronik, perusahaan bata dan mortir berubah menjadi perusahaan online. Dengan sifatnya yang meningkat secara eksponensial, transformasi terus berlanjut. Salah satu nilai penting dari setiap perusahaan, yang saling terkait dengan semua sub divisi dan operasi perusahaan, dapat dianggap sebagai reputasi (Seker \& Eryarsoy, 2015). Reputasi merupakan konsep penting bagi organisasi, diperlukan jangka waktu yang relatif cukup lama dan upaya yang konsisten dan berkesinambungan untuk membangun dan menjaganya (Muharromah, 2019). Reputasi merupakan entitas penting bagi lembaga karena dapat mempengaruhi dan menentukan sikap masyarakat terhadap lembaga atau individu. Sebuah lembaga yang memiliki reputasi baik, maka akan memiliki nilai psikologis yang melebihi nilai materialnya (Sjoraida et al., 2021). Termasuk reputasi sebuah brand dan korporat.

Reputasi sebuah brand ataupun korporat di dunia online dapat diukur melalui berbagai cara. Hal ini sejalan dengan pernyataan bahwa konsep reputasi telah berkembang menjadi reputasi online dengan revolusi digital yang disaksikan di zaman kontemporer. Dalam kehidupan nyata, reputasi adalah konsep kualitatif sedangkan di dalam jejaringan media, reputasi dapat diukur (Amin \& Khan, 2020), salah satunya melalui skor SEO. 
Penelitian ini menunjukkan bahwa skor SEO yang diperoleh melalui dua alat menunjukkan angka yang cukup baik, bahkan beberapa di antaranya menunjukkan hasil yang prima. Artinya berdasarkan skor SEO maka dapat dikatakan website marketplace reksadana yang diteliti pada penelitian ini dapat dinilai memiliki reputasi online yang memadai pula. Pada lingkungan ekonomi baru, yang dicirikan sebagai kondisi yang volatil, tidak pasti, kompleks, dan ambigu, dan evolutif, menunjukkan bahwa reputasi online dan tanggung jawab sosial perusahaan memiliki keterkaitan yang saling berhubungan erat (Oncioiu et al., 2020).

Selain berkaitan erat dengan tanggung jawab sosial perusahaan, reputasi juga berkaitan dengan aspek pemasaran dan bisnis. Reputasi bisnis juga dapat ditinjau dari website. Contohnya, sebuah ulasan yang disajikan dalam website ditujukan untuk mengundang konsumen agar membagikan ulasan mereka, hal ini dapat memengaruhi reputasi online bisnis di industri (Chen \& Tabari, 2017). Reputasi online adalah reputasi yang melibatkan reputasi perusahaan yang dibuat di lingkungan online. Lingkungan media sosial adalah salah satu lingkungan online. Reputasi online dibangun oleh sekelompok orang yang berbagi dan berkolaborasi secara online dan melalui mesin pencari (Tafesse, 2012). Di sisi lain, website menjadi media informasi yang lebih dinamis dan dapat membangun reputasi online (Dipa et al., 2021). Hal ini menunjukkan pentingnya reputasi online dan pengelolaannya pada sebuah website.

Manajemen reputasi online adalah cara untuk memantau dan mengelola reputasi perusahaan, dengan tujuan menghilangkan ulasan negatif pada hasil mesin pencari (Attuluri \& Mehta, 2018). Reputasi online mampu mendorong kepercayaan seseorang untuk bertransaksi secara online dan membangun citra professional (Sugiono, 2020). Oleh karena itu, setiap marketplace reksadana online sudah sepatutnya mempertimbangkan faktor aksesibilitas dan skor SEO dalam mengelola reputasi perusahaan guna meningkatkan kepercayaan investor dan calon investor untuk bertransaksi di platform online yang mereka miliki.

Berdasarkanhasilpengecekkanaksesibilitas dan skor SEO melalui alat pengecekan terhadap sejumlah marketplace reksadana online, maka diketahui terdapat kebutuhan untuk menggugah kesadaran manajemen untuk meningkatkan kualitas aksesibilitas pada setiap platform nya. Walaupun skor SEO tiap platform telah menunjukkan angka yang cukup baik namun seiring peningkatan kesadaran masyarakat tentang kesetaraan hak dalam aksesibilitas informasi dan kesempatan berinvestasi, bukan 
mustahil akan muncul ketidakpuasan konsumen terhadap performa platform investasi online yang tersedia saat ini.

Ketidakpuasan konsumen terhadap platform dapat muncul ke permukaan dan ramai dibicarakan secara online. Hal ini tentu akan membahayakan reputasi perusahaan secara online. Popularitas dan jangkauan platform ulasan online pada saat ini telah berkembang pesat, terdapat peningkatan tekanan terhadap perusahaan untuk mempertahankan reputasi online yang sempurna. Di sisi lain, berinvestasi dalam produk dan layanan guna menghasilkan peringkat yang lebih baik, merupakan tantangan yang cukup berat pula. Maka, setiap perusahaan pasti memiliki resiko untuk mengalami kegagalan yang mengarah pada ulasan negatif. Berurusan dengan ulasan negatif merupakan hal yang menantang, karena tidak seperti ulasan yang beredar dari mulut ke mulut atau offline, ulasan negatif yang tersebar secara online tersebut dapat bertahan lebih permanen dan perusahaan tidak dapat menghapusnya secara selektif, atau memilih untuk tidak ditinjau sama sekali. Untuk mengelola ulasan yang tidak menguntungkan, perusahaan sering menggunakan praktik yang dipertanyakan seperti ulasan semu, meminta ulasan positif dengan imbalan tunjangan, mengancam tindakan hukum terhadap pengulas negatif, dan menggunakan non-klausul penghinaan dalam kontrak penjualan yang menetapkan denda jika konsumen menulis ulasan negatif (Proserpio \& Zervas, 2014)

Oleh karena itu diperlukan manajemen reputasi online yang tak hanya bersifat menangani isu negatif yang muncul, namun juga mengantisipasi peluang isu sebelum muncul ke permukaan. Salah satunya dengan menyamakan persepsi, kepentingan dan kolaborasi dengan pihak pengembang website agar lebih memastikan faktor aksesibilitas, sebelum kesenjangan aksesibilitas ini dikeluhkan publik yang dapat menurunkan tingkat kepercayaan publik terhadap perusahaan.

\section{SIMPULAN}

Berdasarkan hasil penelitian diketahui bahwa website marketplace reksadana online yang diteliti pada penelitian ini masih memiliki sejumlah masalah aksesibilitas. Masalah tersebut berpotensi menghambat aksesibilitas informasi bagi para pengguna, termasuk dari kalangan penyandang disabilitas. Hal ini dikhawatirkan akan menjadi kendala teknis dan mengurangi peluang mereka untuk berpartisipasi sebagai investor dan calon investor.

Adapun jenis dampak aksesibilitas terbanyak masuk ke dalam kategori serius. Jenis isu terbanyak antara lain: kontras warna pada setiap elemen, pengisian landmark pada setiap konten, serta ketersediaan teks yang 
dapat dilihat pada setiap tautan. Di samping itu diketahui pula bahwa akibat sejumlah isu yang muncul pada pengecekkan aksesibilitas ini berdampak pada pengguna disabilitas dari kalangan penyandang hambatan penglihatan. Mulai dari penyandang buta warna, low vision, tunanetra, hingga buta tuli, serta penyandang hambatan mobilitas dan kognitif.

Sedangkan untuk hasil pengecekkan skor SEO pada sejumlah website marketplace reksadana online diketahui bahwa skor yang dihasilkan dari dua alat pengecekkan menunjukkan angka yang cukup baik. Namun demikian, aksesibilitas website tetap perlu ditingkatkan, sebab tak dapat dipungkiri bahwa hambatan aksesibilitas terhadap website dapat mempengaruhi performa dan kepuasan pengguna yang dapat berdampak pada reputasi perusahaan. Oleh karena itu diharapkan pihak manajemen dari marketplace reksadana online dapat mempertimbangkan pentingnya aksesibilitas informasi pada website mereka sebagai bagian dari manajemen reputasi online.

\section{DAFTAR PUSTAKA}

Abou-Zahra, S., \& Brewer, J. (2019). Standards, guidelines, and trends. In Y. Yesilada \& S. Harper (Eds.), Web accessibility. the human-computer interaction series (pp. 629-649). https://doi.org/10.1007/978-14471-7440-0_32

AccessiBe. (2019). 5 Reasons why web accessibility should be your priority in
2019.

Amin, F., \& Khan, M. F. (2020). Online reputation and stress: discovering the dark side of social media. FIIB Business Review, 10(2), 181-192. https://doi. org/10.1177/2319714520948171

Arasid, W., Abdullah, A. G., Wahyudin, D., Abdullah, C. U., Widiaty, I., Zakaria, D., Amelia, N., \& Juhana,A. (2018).An analysis of website accessibility in higher education in indonesia based on wcag 2.0 guidelines. IOP Conference Series: Materials Science and Engineering, 306(012130). https://doi. org/10.1088/1757-899X/306/1/012130

Attuluri, S., \& Mehta, A. (2018). A review on online reputation management for doctors at indian corporate hospitals. International Journal of Advanced Research, 6(6), 194198. https://doi.org/10.21474/ijar01/7201

Baihaqqy, M. R. I., Disman, Nugraha, Sari, M., \& Ikhsan, S. (2020). The effect of financial literacy on the investment decision. Budapest International Research and Critics Institute-Journal (BIRCI-Journal), 3(4), 3073-3083. https://doi.org/10.2139/ ssrn. 1950040

Calvo, R., Seyedarabi, F., \& Savva, A. (2016). Beyond web content accessibility guidelines. expert accessibility reviews. ACM International Conference Proceeding Series, 77-84. https://doi. org/10.1145/3019943.3019955

Chen, W., \& Tabari, S. (2017). A study of negative customer online reviews and managerial responses on social media - case study of the marriott hotel group in Beijing. Journal of Marketing and Consumer Research, 41, 53-64.

Deastu, A. D. (2020). Analisis aksesibilitas website pemerintah provinsi di Indonesia menggunakan pedoman web content 
accessible guidelines 2.0. Jurnal Repositor, 2(10). https://doi.org/10.22219/repositor. v2i10.1056

Destinasi Bandung. (2021). Pengelolaan keuangan dan investasi dimasa pandemi dalam kemandirian ekonomi difabel. Destinasibandung.Co.Id. https://www. destinasibandung.co.id/pengelolaankeuangan-dan-investasi-dimasa-pandemidalam-kemandirian-ekonomi-difabel.html

Dipa, A. K., Hafiar, H., \& Rahmat, A. (2021). Website accessibility 3 best universities in west Sumatra regarding online reputation. Nyimak: Journal of Communication, 5(2), $295-309$.

Fernández-Díaz, E., Iglesias-Sánchez, P. P., \& Jambrino-Maldonado, C. (2020). Exploring who communication during the COVID 19 pandemic through the who website based on W3C guidelines: Accessible for all? International Journal of Environmental Research and Public Health, 17(16), 1-17. https://doi.org/10.3390/ijerph17165663

Frandini, M. A., Aknuranda, I., \& Rokhmawati, R. I. (2018). Analisis tingkat aksesibilitas halaman utama situs web perguruan tinggi di Indonesia berdasarkan WCAG 2.0. Pengembangan Teknologi Informasi Dan Ilmu Komputer, 2(3), 1045-1053.

Frazão, T., \& Duarte, C. (2020). Comparing accessibility evaluation plug-ins. Proceedings of the 17th International Web for All Conference, W4A 2020. https://doi. org/10.1145/3371300.3383346

Gonçalves, R., Martins, J., \& Branco, F. (2014). A review on the Portuguese enterprises web accessibility levels - A website accessibility high level improvement proposal. Procedia Computer Science, 27, 176-185. https:// doi.org/10.1016/j.procs.2014.02.021

Hafiar, H., Subekti, P., Setianti, Y., \& Dipa, A.
K. (2022). Accessibility of Information on Marketplace Websites for Consumers with Disabilities. Library Philosophy and Practice (Ejournal), 6010. https:// digitalcommons.unl.edu/libphilprac/6010

Irfan. (2020). 9 Marketplace reksadana online terbaik 2021, ulas kelebihan dan kekurangannya. Irfan.Id. https://irfan.id/ marketplace-reksadana-online-terbaik/

Ismail, A., \& Kuppusamy, K. S. (2019). Web accessibility investigation and identification of major issues of higher education websites with statistical measures: A case study of college websites. Journal of King Saud University - Computer and Information Sciences, xxxx. https://doi.org/10.1016/j. jksuci.2019.03.011

Ismail, A., Kuppusamy, K. S., \& Nengroo, A. S. (2018). Multi-tool accessibility assessment of government department websites:a case-study with JKGAD. Disability and Rehabilitation: Assistive Technology, 13(6), 504-516. https://doi.org/10.1080/17 483107.2017 .1344883

Kawa, A., \& Wałęsiak, M. (2019). Marketplace as a key actor in e-commerce value networks. Logforum: Scientific Journal of Logistics, 15(4), 521-529. https://doi. org/10.17270/J.LOG.2019.351

Kesswani, N., \& Kumar, S. (2016). Accessibility analysis of websites of educational institutions. Perspectives in Science, 8, 210-212. https://doi.org/10.1016/j. pisc. 2016.04.031

Kimmel, A. J. (2004). Rumors and the financial marketplace. Journal of Behavioural Finance, 5(3), 134-141. https://doi. org/10.1207/s15427579jpfm0503

Kitterman, T. (2021). Report : digital content accessibility has big impact on brand reputation. PR Daily. 
Liivamägi, K. (2016). Investor education and trading activity on the stock market. Baltic Journal of Economics, 16(2), 114-131. https://doi.org/10.1080/140609 9X.2016.1189058

Masyhur, F. (2015). Evaluasi aksesibilitas website resmi kementerian dan lembaga menggunakan pedoman WCAG 2. 0. Temu Ilmiah Peneliti Kominfo 2015.

Muharromah, I. A. (2019). Pengelolaan reputasi pemanfaatan ilmu pengetahuan dan teknologi nuklir melalui media online. PRofesi Humas, 4(1), 96-113. https://doi. org/10.24198/prh.v4i1.19616

Needham, S. (2021). What is the SEO Score? Siteimprove.

Oncioiu, I., Popescu, D. M., Anghel, E., Petrescu, A. G., Bîlcan, F. R., \& Petrescu, M. (2020). Online company reputation-a thorny problem for optimizing corporate sustainability. Sustainability (Switzerland), 12(5547), 15-17. https://doi.org/10.3390/ su12145547

Proserpio, D., \& Zervas, G. (2014). Online reputation management: estimating the impact of management responses on consumer reviews. SSRN Electronic Journal. https://doi.org/10.2139/ ssrn. 2521190

Rubano, V., \& Vitali, F. (2020). Experiences from declarative markup to improve the accessibility of HTML. Presented at Balisage: The Markup Conference 2020, Washington, DC, July 27 - 31, 2020. In Proceedings of Balisage: The Markup Conference 2020. Balisage Series on Markup Technologies, 25. https://doi. org/10.4242/balisagevol25.vitali01

Saripudin, S., Djohar, A., Rohendi, D., \& Abdullah, A. G. (2019). Comparison of accessibility of OER repositories of developed countries and developing countries based on WCAG 2.0 guidelines. Journal of Physics: Conference Series, 1402. https://doi.org/10.1088/1742$6596 / 1402 / 7 / 077042$

Seker, S. E., \& Eryarsoy, E. (2015). Generating digital reputation index: a case study. Procedia - Social and Behavioral Sciences, 195, 1074-1080. https://doi.org/10.1016/j. sbspro.2015.06.151

Sfenrianto, S., Wijaya, T., \& Wang, G. (2018). Assessing the buyer trust and satisfaction factors in the E-marketplace. Journal of Theoretical and Applied Electronic Commerce Research, 13(2), 43-57. https://doi.org/10.4067/S071818762018000200105

Sims, G. (2016a). Accessibility prioritization: laying the foundation with a strategic plan [Part 1].

Sims, G. (2016b). Accessibility prioritization: your tactical roadmap [Part 2].

Sjoraida, D. F., Dewi, R., Adi, A. N., \& Dipa, A. K. (2021). Penggunaan media sosial dalam membangun reputasi anggota legislatif di Jawa Barat. PRofesi Humas, 6(1), 89-110. https://doi.org/10.24198/prh.v6i1.32112

Sugiono, S. (2020). Online reputation conceptualization. Diakom : Jurnal Media Dan Komunikasi, 3(1), 65-76. https://doi. org/10.17933/diakom.v3i1.74

Tafesse,Y.Z.(2012). Therole of onlinereputation management in strategic business decisions in ericsson acknowledgment. June, 92.

Taylor, Z. W. (2019). Web (in)accessible: Supporting access to Texas higher education for students with disabilities. Texas Education Review, 7(2), 60-75. https://doi.org/http://dx.doi.org/10.26153/ tsw/2285

Vallee, B., \& Zeng, Y. (2018). Marketplace 
lending: a new banking paradigm? SSRN

Electronic Journal. https://doi.org/10.2139/ ssrn.3102984

Veglis, A., \& Giomelakis, D. (2020). Search engine optimization. Future Internet, 12(1), 506-510. https://doi.org/10.3390/ fi12010006

Velásquez, J. D., Estévez, P. A., Yasuda, H., Aoki, T., \& Vera, E. (2004). Intelligent Web site: understanding the visitor behavior. Lecture Notes in Computer Science (Including Subseries Lecture Notes in Artificial Intelligence and Lecture Notes in Bioinformatics), 3213, 140-147. https:// doi.org/10.1007/978-3-540-30132-5_24

Yu, H., \& Han, E. (2021). Developing a measure for online shopping mall reputation (OSMR). Sustainability (Switzerland), 13(7). https://doi.org/10.3390/su13073818

Zeng, X., \& Parmanto, B. (2004). Web content accessibility of consumer health information web sites for people with disabilities: A cross sectional evaluation. Journal of Medical Internet Research, 6(2), 1-21. https://doi.org/10.2196/jmir.6.2.e19 